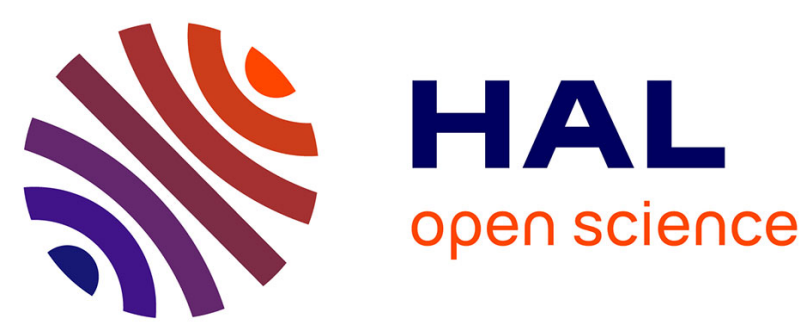

\title{
La diffusion des neutrons
}

\author{
A. Guinier
}

\section{- To cite this version:}

A. Guinier. La diffusion des neutrons. Revue de Physique Appliquée, 1976, 11 (1), pp.82-82. 10.1051/rphysap:0197600110108200 . jpa-00244046

\section{HAL Id: jpa-00244046 https://hal.science/jpa-00244046}

Submitted on 1 Jan 1976

HAL is a multi-disciplinary open access archive for the deposit and dissemination of scientific research documents, whether they are published or not. The documents may come from teaching and research institutions in France or abroad, or from public or private research centers.
L'archive ouverte pluridisciplinaire HAL, est destinée au dépôt et à la diffusion de documents scientifiques de niveau recherche, publiés ou non, émanant des établissements d'enseignement et de recherche français ou étrangers, des laboratoires publics ou privés. 


\title{
LA DIFFUSION DES NEUTRONS
}

\author{
A. GUINIER
}

Physique des Solides, Université Paris-Sud, 91405 Orsay, France

\begin{abstract}
Résumé. - On rappellera les bases physiques de la diffusion des neutrons en insistant sur les caractéristiques du phénomène qui la différencie de la diffusion des rayons $X$, en particulier l'existence d'une diffusion inélastique dont le spectre en énergie peut être déterminé. On montrera les possibilités spéciales des neutrons liées à leur faible absorption dans la matière et leur interaction avec les moments magnétiques atomiques.

On donnera une revue des appareillages actuellement à la disposition des chercheurs français auprès des réacteurs nationaux et du réacteur à haut flux de Grenoble, en précisant l'ordre de grandeur de leurs performances respectives.

On montrera, par quelques exemples de résultats obtenus en France, les informations nouvelles que les neutrons ont récemment apportées dans leurs différents domaines d'application : structures de cristaux et de substances amorphes, structures magnétiques, conformation des macromolécules, biologiques ou polymères, phonons et magnons, dynamique moléculaire, topographie de Lang aux neutrons.
\end{abstract}

Abstract. - The physical basis of the scattering of neutrons is discussed : emphasis is put on the characteristics which differentiate that phenomenon from X-Ray Scattering. In particular, the energy spectrum of the inelastically scattered neutrons may be determined experimentally. The possibilities of the neutron scattering due to their weak absorption coefficient in matter and to their interaction with atomic magnetic moments will be described. The experimental facilities which the french researchers can use presently at I. L. L. or at the national reactors will be reviewed, and their respective performances will be compared. Some examples of results recently obtained in France show the nature of the new informations brought by neutron scattering in various fields : structure of crystals and amorphous substances, magnetic structures, high polymers and biological macromolecules, phonons and magnons, molecular dynamics, Lang topography. 